\title{
Milk yield and reproductive performance of dairy heifers and cows supplemented with polyunsaturated fatty acids
}

\author{
Félix Gonzalez(1), Rodrigo Muiño(2), Víctor Pereira( ${ }^{(3)}$, Diego Martinez ${ }^{(4)}$, Cristina Castillo(3), \\ Joaquín Hernández ${ }^{(3)}$ and José Luis Benedito(3)
}

\begin{abstract}
(1)Universidade Federal do Rio Grande do Sul, Faculdade de Veterinária, Avenida Bento Gonçalves, no 9.090, CEP 91540-000 Porto Alegre, RS, Brazil. E-mail: felixgonzalez.ufrgs@gmail.com (2)Centro Veterinario Meira, Calle San Roque, 1 B, 27240 Meira, Galicia, Spain. E-mail: rodrigomuino@colvet.es ${ }^{(3)}$ Universidad de Santiago de Compostela, Facultad de Veterinaria, Departamento de Patología Animal, 27002 Lugo, Galicia, Spain. E-mail: victor.pereira@usc.es, cristina.castillo@usc.es, joaquin.hernandez@usc.es, joseluis.benedito@usc.es

(4)Aranda de Duero, Burgos, Spain. E-mail: dmartinez@nuteriberia.com
\end{abstract}

\begin{abstract}
The objective of this work was to determine productive and fertility responses of Holstein-Friesian heifers and cows to supplementation with extruded linseed and soybean as sources of polyunsaturated fatty acids (PUFAs). Supplementation had a positive effect on profitability, with significant increases in milk yield in supplemented cows, but not in heifers. Treatments had no effect on milk fat content, but higher milk protein contents were observed with supplementation. A higher conception rate was found for supplemented heifers, but not for cows. Fat sources containing PUFAs are recommended for dairy cattle supplementation, since they improve fertility in heifers and milk yield in cows.

Index terms: extruded linseed, extruded soybean, fertility, long-chain fatty acids, milk composition, PUFA.

\section{Produção de leite e desempenho reprodutivo de novilhas e vacas leiteiras suplementadas com ácidos graxos poli-insaturados}

\begin{abstract}
Resumo - O objetivo deste trabalho foi determinar a resposta produtiva e de fertilidade, de novilhas e vacas Holandesas, à suplementação com extratos de linhaça e soja como fontes de ácidos graxos poli-insaturados (PUFAs). A suplementação teve efeito positivo sobre a rentabilidade, com aumento significativo na produção de leite de vacas suplementadas, mas não na de novilhas. Os tratamentos não tiveram efeito sobre o conteúdo de gordura no leite, mas maiores conteúdos de proteína láctea foram observados com a suplementação. Houve maior taxa de concepção em novilhas suplementadas, mas não em vacas. Fontes de gordura contendo PUFAs são recomendadas para suplementação do gado leiteiro, uma vez que melhoram a fertilidade de novilhas e a produção de leite de vacas.
\end{abstract}

Termos para indexação: linhaça extruída, soja extruída, fertilidade, ácidos graxos de cadeia longa, composição do leite, PUFA.

\section{Introduction}

During the last decades, long-chain fatty acids (LCFA) have been incorporated into cattle feed with the intention of enhancing the energy density of the diet, mostly to improve energy balance for postpartum cows. The addition of LCFA to feed, in moderate quantities $(2-3 \%$ dry matter, DM) during early postpartum of dairy cows, increases milk yield and improves cow reproduction, with a positive response on conception rate of up to $17 \%$ (Staples et al., 1998).

The main polyunsaturated fatty acid (PUFA) in most seed lipids is linoleic acid (C18:2 n-6), whereas linolenic acid (C18:3 n-3) predominates in most forage lipids (Palmquist \& Jenkins, 1980). PUFAs from the n-6 and n-3 families seem to have their most remarkable effects on cattle reproductive performance (Mattos et al., 2000). However, it is not completely clear whether those effects are mediated by the PUFAs themselves or by intermediate metabolites produced during biohydrogenation in the rumen (Santos et al., 2008).

Fat sources rich in n-3 fatty acids are inhibitors of cyclooxygenase in the endometrial tissue of dairy cows (Staples et al., 1998), and, therefore, endometrial secretion of $\mathrm{PGF}_{2 \alpha}$ may be suppressed, which can potentially prevent early embryonic death (Silvestre et al., 2011). Moreover, PUFAs supplied 21 days before 
parturition contribute to a faster recovery of the uterus and to improve cow fertility (Ambrose \& Kastelic, 2003). Finally, the intake of $n-6$ fatty acids during late gestation and early lactation contributes to improve embryo quality and development (Fouladi-Nashta et al., 2007). However, the effects of PUFAs on the reproductive performance of cows are still controversial: some authors claim that it has no effect on this trait (Scott et al., 1995; Petit \& Twagiramungu, 2006; Juchem, 2007; Fuentes et al., 2008), while others maintain that it can improve fertility (McNamara et al., 2003; Ambrose et al., 2006).

Studies with dairy cows supplemented with PUFAs are also controversial as to their effects on milk yield. Kennelly \& Khorasani (1993) used whole flaxseed at different percentages $-0.5,10$, and $15 \%$ - of DM intake (DMI) and found no effect on milk yield. Petit (2003) also did not find differences in milk yield using different PUFA-supplemented diets. However, Petit et al. (2004) reported higher milk yield in cows fed with PUFAs. Similar results were obtained by Dirandeh et al. (2013), with higher milk yield in cows fed on unsaturated dietary fat.

The objective of this work was to determine productive and fertility responses of Holstein-Friesian heifers and cows to supplementation with extruded linseed and soybean as sources of PUFAs.

\section{Materials and Methods}

The study was done at a high-producing dairy farm in Galicia, in northwest Spain. The experiment was conducted with lactating Holstein-Friesian cows $(n=51)$ and heifers $(\mathrm{n}=61)$. Multiparous cows had a preceding lactation of over $11,959 \mathrm{~kg}$ of milk, according to the official milk recording data collected in 2010, during 305 days. The animals were milked twice a day and housed in free stalls with straw beds.

Cows and heifers were randomly assigned to two experimental groups: 66 animals (36 heifers and 30 cows), which were subjected to a commercial concentrate (Fertilac, Núter Feed, Aranda de Duero, Spain) containing fat supplements based on extruded linseed (source of linolenic acid) and soybean oil (source of linoleic acid); and 46 animals (25 heifers and 21 cows), which did not receive the fat supplements, but otherwise received the same diet as the supplemented animals (Table 1). The diets were isocaloric and isoproteic (Table 2), and calculated to meet the total energy and protein requirements of animals with $650-\mathrm{kg}$ mean body weight, producing $37 \mathrm{~kg}$ per day of milk, with $3.2 \%$ fat and $3.1 \%$ protein (National Research Council, 2001). For the first group, the supplement was offered from 3 weeks before calving until 2 months of lactation. During the pretrial period (3 months), all animals received the same total mixed feed, without any supplement, and were housed in the same barn.

Milk daily yield was recorded, and milk samples were taken for analysis of fat and protein contents. The milk samples were stored at $0-8^{\circ} \mathrm{C}$, before being sent to a certified laboratory. In the laboratory, the milk samples were cooled to $4^{\circ} \mathrm{C}$, and azidiol $0.33 \%$ was added as a preservative, until analysis. Before analysis, the samples were heated in a water bath $\left(37-42^{\circ} \mathrm{C}\right)$ and further processed in an infrared spectrophotometer MilkoScan FT 6000 (Foss, Hillerod, Denmark) to determine fat and protein contents.

After 28 days of calving, transrectal ultrasonography examination of ovaries and uterus was performed in all animals, fortnightly, using a real-time, full-digital

Table 1. Composition ( $\%$ dry matter basis) of the diets for the supplemented and control groups.

\begin{tabular}{lcc}
\hline Ingredients & Supplemented group & Control group \\
\hline Corn (silage) & 42.63 & 42.63 \\
Ryegrass (silage) & 10.15 & 10.15 \\
Hay & 1.68 & 1.68 \\
Cane molasses & 0.75 & 0.75 \\
Calcium soap & 0.92 & 1.12 \\
Magnesium oxide & 0.27 & 0.27 \\
Vitamins and minerals ${ }^{(1)}$ & 0.19 & 0.19 \\
Dried corn & 12.05 & 12.05 \\
Soy 44 & 10.20 & 10.75 \\
Wheat & 7.47 & 7.47 \\
Rapeseed meal & 5.54 & 6.09 \\
Barley & 4.36 & 4.36 \\
Sodium bicarbonate & 1.01 & 1.01 \\
Calcium bicarbonate & 0.96 & 0.96 \\
Sodium chloride & 0.47 & 0.47 \\
Extruded linseed & 0.77 & - \\
Extruded soybean & 0.54 & - \\
\hline
\end{tabular}

${ }^{(1)}$ Composition of the vitamin-mineral corrector (Núter Feed, Aranda de Duero, Spain) per kg: 3,000,000 IU vitamin A; 750,000 IU vitamin D3; $12,500 \mathrm{IU}$ vitamin E; $20,500 \mathrm{mg}$ zinc oxide; 7,500 $\mathrm{mg}$ zinc chelate; 5,500 mg copper sulfate; $750 \mathrm{mg}$ copper chelate; $200 \mathrm{mg}$ sodium selenite; $1,904 \mathrm{mg}$ calcium; and $222 \mathrm{mg}$ sodium. 
B mode veterinary ultrasound scanner, equipped with a $6.5 \mathrm{MHz}$ multi-frequency linear rectal probe KX 5200V (Kaixin Electronic Instrument Co., Ltd., Xuzhou, Jiangsu, China). Uterine involution after calving, follicular dynamics, and pregnancy diagnostic were assessed in this procedure.

In order to eliminate possible variations in estrus detection between groups, ovulation was synchronized in all animals according to Pursley et al. (1995), using two GnRH treatments Gonadorelin diacetate

Table 2. Analysis of the composition (\% dry matter) of totally mixed feeds offered to the supplemented and control groups.

\begin{tabular}{|c|c|c|}
\hline Nutrients $^{(1)}$ & Supplemented group & Control group \\
\hline Dry matter (kg) & 46.047 & 46.047 \\
\hline NEL (kcal kg-1) & 0.764 & 0.764 \\
\hline Crude protein (g) & 7.321 & 7.321 \\
\hline $\operatorname{Starch}(g)$ & 12.298 & 12.29 \\
\hline Sugar (g) & 1.064 & 1.069 \\
\hline NSC (g) & 18.591 & 18.564 \\
\hline Crude fiber (g) & 7.691 & 7.697 \\
\hline $\operatorname{ADF}(g)$ & 8.775 & 8.781 \\
\hline NDF $(g)$ & 14.973 & 14.973 \\
\hline $\operatorname{NDFf}(g)$ & 12.057 & 12.058 \\
\hline Ether extract (g) & 1.735 & 1.738 \\
\hline Calcium (g) & 0.354 & 0.363 \\
\hline Phosphorus (g) & 0.161 & 0.161 \\
\hline Magnesium (g) & 0.162 & 0.162 \\
\hline Potassium (g) & 0.565 & 0.566 \\
\hline Sodium (g) & 0.307 & 0.307 \\
\hline Chlorine (g) & 0.231 & 0.23 \\
\hline Sulfur (g) & 0.126 & 0.126 \\
\hline Zinc (mg) & 25.845 & 25.84 \\
\hline Selenium (mg) & 0.185 & 0.185 \\
\hline Cinder $(g)$ & 3.426 & 3.44 \\
\hline Vitamin A (1,000 UI) & 2.769 & 2.769 \\
\hline Vitamin $\mathrm{D}_{3}(1,000 \mathrm{UI})$ & 0.692 & 0.692 \\
\hline Vitamin E (mg) & 11.538 & 11.536 \\
\hline Copper (mg) & 6.461 & 6.46 \\
\hline Humidity (kg) & 53.953 & 53.963 \\
\hline Lysine/methionine & 3.591 & 3.591 \\
\hline Lysine $\left(\mathrm{g} \mathrm{kg}^{-1}\right)$ & 4.01 & 4.069 \\
\hline Methionine $\left(\mathrm{g} \mathrm{kg}^{-1}\right)$ & 1.053 & 1.068 \\
\hline Stearic acid $(\mathrm{g})$ & 0.007 & 0 \\
\hline Oleic acid (g) & 0.03 & 0 \\
\hline Linoleic acid (g) & 0.55 & 0.02 \\
\hline Linolenic acid $(\mathrm{g})$ & 0.59 & 0.02 \\
\hline
\end{tabular}

(1)NEL, net energy for lactation; NSC, nonstructural carbohydrates; ADF, acid detergent fiber; NDF, neutral detergent fiber; and NDFf, neutral detergent fiber forage.
$0.05 \mathrm{mg}$ (Ceva Salud Animal, Barcelona, Spain), with an interval of 9 days; and a $\mathrm{PGF}_{2 \alpha}$ treatment Luprostiol 7.5 mg (Virbac España S.A., Barcelona, Spain), 7 days after the first GnRH treatment. Then, all synchronized animals were inseminated, always by the same technician, at 14-16 hours after the second dose of GnRH, with frozen-thawed semen. Pregnancy diagnosis was performed 30 days after the insemination. The nonpregnant animals were resynchronized and inseminated at a fixed time.

The following reproductive parameters were considered: conception rate (\%) at first artificial insemination (AI); interval (days) from calving to first $\mathrm{AI}$; insemination/conception rate; and number of open days (interval from calving to a new conception).

Considering the differences in lactation physiology of heifers and cows, statistical analyses were performed for both animals classes separately. Productive and reproductive parameters were tested for normality, according to the Kolmogorov test. All productive parameters (milk yield, milk corrected yield at $3.5 \%$ fat $/ 3.2 \%$ protein, milk fat, milk protein, and milk fat/protein ratio) were normalized by $\log$ transformation. Descriptive statistics for all variables were tabulated. Differences between normalized means were established using the t-Student test, taking into account the Levene test to assess the equality of variances. Conception rate at first AI was evaluated using a chi-square test. All statistical analyses were performed using the SPSS 18 package. Significance for differences was declared at 5\% probability; and for tendency, at $10 \%$ probability.

\section{Results and Discussion}

A better conception rate was obtained in supplemented heifers (Table 3). Days from calving to first AI did not differ between treatments in the heifer group; however, a tendency $(\mathrm{p}=0.052)$ for a lower AI/ conception rate was observed in the supplemented group, whereas open days were higher in the non-supplemented group. The cows, however, did not show differences between treatments in their reproductive parameters.

Total milk yield was higher in supplemented cows (Table 4). In the analyzed period (17 months), supplemented cows produced $6.3 \%$ more milk than the 
control cows. Total milk production, however, did not differ between heifers.

Supplementation with PUFAs resulted in increased milk protein content both in supplemented heifers and cows, but did not have any effect on fat content (Table 4). Consequently, the milk fat/protein ratio was significantly lower in supplemented animals. The use of PUFAs in dairy cow diets has revealed benefits in fertility performance (Mattos et al., 2000, 2002; Ambrose \& Kastelic, 2003) and in milk production (Petit et al., 2004; Dirandeh et al., 2013). It was observed that the supplementation of dairy cattle with extruded linseed and soybean as sources of linoleic and linolenic acids increased total milk yield, but this benefit was not extended to heifers. The supplement also increased the milk protein content in all animals. Supplemented heifers showed a tendency of improving reproductive performance, but this effect was not seen in multiparous cows.

Improved conception rates of heifers have been reported as a consequence of the additional dietary energy provided by the fat supplement, which leads to a higher fertility at first insemination (Staples et al.,
1998). Heifers that receive energy supplement can develop larger follicles, which become larger corpus luteum, producing more progesterone and favoring the maintenance of pregnancy (Mattos et al., 2002). In fact, studies have shown that the diameter of the dominant follicle of lactating dairy cows is larger when they are fed with fat supplements (Ambrose et al., 2006). In addition to these benefits, PUFAs, or their biohydrogenated metabolites, can be absorbed by the uterus and inhibit the production and release of prostaglandin $\mathrm{F}_{2 \alpha}$ in the endometrium at the beginning of pregnancy. This would prevent the regression of the corpus luteum in the ovary and allow the continuous production of progesterone, favoring embryo survival (Bilby et al., 2006; Silvestre et al., 2011). It is likely that the interaction between these mechanisms resulted in the improved tendency observed in the conception rate of supplemented heifers (Table 3).

However, supplementation studies with calcium soap as a source of long-chain fatty acids (Ca-LCFAs) for dairy cow diets have shown controversial results. McNamara et al. (2003) observed that supplementing cows with $0.35-0.5 \mathrm{~kg}$ Ca-LCFA per cow per day

Table 3. Conception rate at first artificial insemination (AI) and mean \pm standard deviation of other reproductive parameters of heifers and cows supplemented or not (control) with polyunsaturated fatty acids ${ }^{(1)}$.

\begin{tabular}{|c|c|c|c|c|}
\hline \multirow[t]{2}{*}{ Reproductive parameter } & \multicolumn{2}{|c|}{ Heifers } & \multicolumn{2}{|c|}{ Cows } \\
\hline & Supplemented & Control & Supplemented & Control \\
\hline Number of animals & 31 & 24 & 30 & 21 \\
\hline Conception rate $(\%)$ & $48.0^{*}$ & 25.0 & 30.0 & 38.0 \\
\hline Days from calving to $1^{\text {st }} \mathrm{AI}$ & $75.42 \pm 21.46$ & $69.33 \pm 15.77$ & $69.12 \pm 21.27$ & $72.15 \pm 16.13$ \\
\hline $\mathrm{AI} /$ conception rate & $1.68 \pm 0.83^{*}$ & $2.67 \pm 1.81$ & $2.33 \pm 1.37$ & $2.30 \pm 1.26$ \\
\hline Open days & $95.96 \pm 30.40 * *$ & $125.20 \pm 50.99$ & $109.87 \pm 48.14$ & $116.95 \pm 52.94$ \\
\hline
\end{tabular}

${ }^{(1)}$ The comparisons were made between animals of the same group (heifers or cows). ** and * Significant differences and tendency, at 5 and $10 \%$ probability, respectively.

Table 4. Mean \pm standard deviation of productive parameters of heifers and cows, supplemented or not (control) with polyunsaturated fatty acids ${ }^{(1)}$.

\begin{tabular}{|c|c|c|c|c|}
\hline \multirow[t]{2}{*}{ Productive parameter } & \multicolumn{2}{|c|}{ Heifers } & \multicolumn{2}{|c|}{ Cows } \\
\hline & Supplemented & Control & Supplemented & Control \\
\hline Number of animals & 36 & 25 & 30 & 21 \\
\hline Number of observations & 843 & 1,035 & 1,570 & 1,489 \\
\hline Milk yield (kg per cow per day) & $33.36 \pm 6.44$ & $33.86 \pm 7.23$ & $40.64 \pm 11.50 * *$ & $38.21 \pm 10.61$ \\
\hline Corrected milk yield $^{(2)}$ & $36.39 \pm 7.00$ & $36.60 \pm 8.28$ & $44.54 \pm 12.84 * *$ & $41.73 \pm 12.22$ \\
\hline Milk fat content $(\%)$ & $3.89 \pm 0.76$ & $3.85 \pm 0.80$ & $3.95 \pm 0.86$ & $3.95 \pm 0.85$ \\
\hline Milk protein content $(\%)$ & $3.26 \pm 0.30 * *$ & $3.15 \pm 0.29$ & $3.20 \pm 0.32 * *$ & $3.10 \pm 0.31$ \\
\hline Milk fat/protein ratio & $1.23 \pm 0.19 * *$ & $1.30 \pm 0.27$ & $1.38 \pm 0.26^{* *}$ & $1.46 \pm 0.30$ \\
\hline
\end{tabular}

${ }^{(1)}$ The comparisons were made between animals of the same group (heifers or cows). ${ }^{(2)}$ Corrected to 3.5 fat $/ 3.2$ protein. **Significant differences at $5 \%$ probability. 
improved fertility at first insemination of lactating cows; however, Scott et al. (1995) and Juchem (2007) found no improvement in dairy cow fertility by supplementing them with Ca-LCFA. Scott et al. (1995) reported increased milk production and consequent loss in body condition with this type of supplementation. The cows in the present study did not show any improvement concerning fertility parameters due to supplementation with PUFAs. However, better milk yield and higher milk protein content were observed with the treatment. Therefore, the findings of the present study seem to agree with those of the latter authors.

Sklan et al. (1994) stated that Ca-LCFAs are responsible for a depression in the conception rate at first AI. The authors ascribed this effect to an increased milk yield of supplemented heifers, which lead to a greater negative energy balance. In the present study, the supplemented heifers did not increase their milk yield, which may have favored their reproductive performance, compared to the non-supplemented heifers. The low number of animals evaluated may have contributed to the nonsignificant difference found in the conception rate of supplemented animals, but the observed tendency $(\mathrm{p}=0.08)$ and the effect size obtained between treatments $(48 \%$ conception rate in supplemented animals vs. $25 \%$ in non-supplemented ones) were enough to consider that supplementation has an important effect on this trait.

When cows are fed daily with $0.75 \mathrm{~kg}$ linseed fat, as a source of linolenic acid, fertility is improved (Ambrose et al., 2006). Other researchers, however, did not find beneficial effects of linseed supplementation on fertility (Petit \& Twagiramungu, 2006; Fuentes et al., 2008). Differential responses to fatty acid feeding suggest that PUFAs of the $n-6$ and $n-3$ families are more beneficial than saturated fat acids (Santos et al., 2008). However, it is hard to predict the amount of available PUFA for absorption in the duodenum because most of these acids are biohydrogenated in the rumen. Juchem (2007) pointed out that between 70 and $85 \%$ of the PUFAs are biohydrogenated when cows are fed with unprotected oils. Furthermore, PUFAs from extruded linseed are biohydrogenated in an even greater proportion, and the intermediates of this biohydrogenation process, such as conjugated linoleic acid (CLA), have been related to decreasing milk fat contents (Fuentes et al., 2008). Bauman \& Griinari (2003) reported that trans-10, cis-12-CLA is responsible for causing milk fat reduction in dairy cows. Further studies are necessary to establish if the positive response in heifer fertility indexes observed here might be an effect of the elevated intake of CLA. Therefore, if specific unsaturated fatty acids are important for cattle reproduction, it is critical that future research relating lipids and reproduction aim to improve the extent of delivery of these acids for absorption.

The increased milk yield of supplemented cows (Table 4) agrees with the majority of studies in the literature (Scott et al., 1995; Petit et al., 2004; Dirandeh et al., 2013), although some authors report that the supplementation with fatty acids does not affect milk production (Ward et al., 2002; Gonthier et al., 2005). Petit et al. (2004) suggest that a greater fat mobilization contributes for a greater milk yield in cows supplemented with fatty acids. However, the source of these acids certainly has effect on the different milk yield responses and also on milk fat and protein production. For example, palm oil enables higher increases in milk yield than linseed oil (Fuentes et al., 2008).

The increase in milk protein content in the supplemented groups (Table 4) is in agreement with Petit (2003), who reported higher milk protein contents in cows fed with linseed, and attributed this result to a better energy balance in the diet. However, other authors did not find changes in milk protein when linseed was included in the diet (Kennelly \& Khorasani, 1993; Petit et al., 2004; Ambrose et al., 2006). Furthermore, several studies reported that fat milk content was not affected by linseed supplement (Petit, 2003; Petit et al., 2004), which agrees with results of the present study.

Supplementation had an additional feed cost of $€ 0.30$ per animal per day. Considering that supplemented cows had a mean increase in milk yield of $2.4 \mathrm{~kg}$ per animal per day, supplementation allowed for an additional income of $€ 0.72$ per cow per day, at the current milk price of $€ 0.30 \mathrm{~kg}^{-1}$. The increased milk protein contents may also provide protein premium in prices. According to the current milk quota system in Europe, milk protein production means a bonus, whereas the excess of fat means a penalty.

Regarding the economic analysis of reproductive efficiency, the higher $\mathrm{AI} /$ conception rate observed in supplemented heifers may account for a reduction of one insemination, compared to the control group, which means a saving of $€ 30$ per heifer per year in semen. 


\section{Conclusions}

1. The supplementation with polyunsaturated fatty acids (PUFAs) improves fertility in heifers and milk yield in cows.

2. Although supplementation does not affect milk fat contents, it increases milk protein contents, both in heifers and cows.

3. Supplementation of dairy cattle with PUFAs, at moderate amounts, up to $2-3 \%$ dry matter, has a positive effect on farm profitability.

\section{Acknowledgment}

To the Sat Vilar-Alaxe farm, in Galicia, Spain, for the cooperation in the execution of the present study.

\section{References}

AMBROSE, D.J.; KASTELIC, J.P. Dietary fatty acids and dairy cow fertility. Advances in Dairy Technology, v.15, p.35-47, 2003.

AMBROSE, D.J.; KASTELIC, J.P.; CORBETT, R.; PITNEY, P.A.; PETIT, H.V.; SMALL, J.A.; ZALKOVIC, P. Lower pregnancy losses in lactating dairy cows fed a diet enriched in $\alpha$-linolenic acid. Journal of Dairy Science, v.89, p.3066-3074, 2006. DOI: 10.3168/jds.S0022-0302(06)72581-4.

BAUMAN, D.E.; GRIINARI, J.M. Nutritional regulation of milk fat synthesis. Annual Review of Nutrition, v.23, p.203-227, 2003. DOI: 10.1146/annurev.nutr.23.011702.073408.

BILBY, T.R.; BLOCK, J.; AMARAL, B.C.; SÁ FILHO, O.; SILVESTRE, F.T.; HANSEN, P.J.; STAPLES, C.R.; THATCHER, W.W. Effects of dietary unsaturated fatty acids on oocyte quality and follicular development in lactating dairy cows in summer. Journal of Dairy Science, v.89, p.3891-3903, 2006. DOI: 10.3168/ jds.S0022-0302(06)72432-8.

DIRANDEH, E.; TOWHIDI, A.; ZEINOALDINI, S.; GANJKHANLOU, M.; PIRSARAEI, Z.A.; FOULADI-NASHTA, A. Effects of different polyunsaturated fatty acid supplementations during the postpartum periods or early lactating dairy cows on milk yield, metabolic responses and reproductive performances. Journal of Animal Science, v.91, p.713-721, 2013. DOI: 10.2527/ jas.2012-5359.

FOULADI-NASHTA, A.A.; GUTIERREZ, C.G.; GONG, J.G.; GARNSWORTHY, P.C.; WEBB, R. Impact of dietary fatty acids on oocyte quality and development in lactating dairy cows. Biology of Reproduction, v.77, p.9-17, 2007. DOI: 10.1095/ biolreprod.106.058578.

FUENTES, M.C.; CALSAMIGLIA, S.; SÁNCHEZ, C.; GONZÁLEZ, A.; NEWBOLD, J.R.; SANTOS, J.E.P.; RODRÍGUEZ-ALCALÁ, L.M.; FONTECHA, J. Effect of extruded linseed on productive and reproductive performance of lactating dairy cows. Livestock Science, v.113, p.144-154, 2008. DOI: 10.1016/j.livsci.2007.03.005.
GONTHIER, C.; MUSTAFA, A.F.; OUELLET, D.R.; CHOUINARD, P.Y.; BERTHIAUME, R.; PETIT, H.V. Feeding micronized and extruded flaxseed to dairy cows: effects on blood parameters and milk fatty acid composition. Journal of Dairy Science, v.88, p.748-756, 2005. DOI: $10.3168 / j \mathrm{ds}$. S0022-0302(05)72738-7.

JUCHEM, S.O. Lipid digestion and metabolism in dairy cows: effects on production, reproduction and health. 2007. $234 \mathrm{f}$. Dissertation (Doctorate) - University of California, Davis.

KENNELLY, J.J.; KHORASANI, G.R. Influence of acid treatment of canola meal on rumen fermentation and milk production in dairy cows. In: RESEARCH on canola seed, oil and meal. Winnipeg: Canola Council of Canada, 1993. p.107-122. (Canola Council of Canada. Project Report, 10).

MATTOS, R.; STAPLES, C.R.; THATCHER, W.W. Effects of dietary fatty acids on reproduction in ruminants. Reviews of Reproduction, v.5, p.38-45, 2000. DOI: 10.1530/ror.0.0050038.

MATTOS, R.; STAPLES, C.R.; WILLIAMS, J.; AMOROCHO, A.; McGUIRE, M.A.; THATCHER, W.W. Uterine, ovarian, and production responses of lactating dairy cows to increasing dietary concentrations of menhaden fish meal. Journal of Dairy Science, v.85, p.755-764, 2002. DOI: 10.3168/jds. S0022-0302(02)74133-7.

McNAMARA, S.; BUTLER, T.; RYAN, D.P.; MEE, J.F.; DILLON, P.; O'MARA, F.P.; BUTLER, S.T.; ANGLESEY, D.; RATH, M.; MURPHY, J.J. Effect of offering rumen-protected fat supplements on fertility and performance in spring-calving Holstein-Friesian cows. Animal Reproduction Science, v.79, p.45-46, 2003. DOI: 10.1016/S0378-4320(03)00111-8.

NATIONAL RESEARCH COUNCIL. Nutrient requirements of dairy cattle. $7^{\text {th }}$ ed. Washington: National Academy Press, 2001. 408p.

PALMQUIST, D.L.; JENKINS, T.C. Fat in lactation rations: review. Journal of Dairy Science, v.63, p.1-14, 1980. DOI: 10.3168/jds. S0022-0302(80)82881-5.

PETIT, H.V. Digestion, milk production, milk composition, and blood composition of dairy cows fed formaldehyde treated flaxseed or sunflower seed. Journal of Dairy Science, v.86, p.2637-2646, 2003. DOI: $10.3168 /$ jds.S0022-0302(03)73859-4.

PETIT, H.V.; GERMIQUET, C.; LEBEL, D. Effect of feeding whole, unprocessed sunflower seeds and flaxseed on milk production, milk composition, and prostaglandin secretion in dairy cows. Journal of Dairy Science, v.87, p.3889-3898, 2004. DOI: 10.3168/jds.S0022-0302(04)73528-6.

PETIT, H.V.; TWAGIRAMUNGU, H. Conception rate and reproductive function of dairy cows fed different fat sources. Theriogenology, v.66, p.1316-1324, 2006. DOI: $10.1016 / \mathrm{j}$. theriogenology.2006.04.029.

PURSLEY, J.R.; MEE, M.O.; WILTBANK, M.C. Synchronization of ovulation in dairy cows using $\mathrm{PGF}_{2 \alpha}$ and $\mathrm{GnRH}$. Theriogenology, v.44, p.915-923, 1995. DOI: 10.1016/0093-691X(95)00279-H.

SANTOS, J.E.P.; BILBY, T.R.; THATCHER, W.W.; STAPLES, C.R.; SILVESTRE, F.T. Long chain fatty acids of diet as factors influencing reproduction in cattle. Reproduction in Domestic 
Animals, v.43, p.23-30, 2008. DOI: 10.1111/j.1439-0531.2008.0 1139.x.

SCOTT, T.A.; SCHAVER, R.D.; ZEPEDA, L.; YANDELL, B.; SMITH, T.R. Effects of rumen-inert fat on lactation, reproduction, and health of high producing Holstein herds. Journal of Dairy Science, v.78, p.2435-2451, 1995. DOI: 10.3168/jds. S0022-0302(95)76872-2.

SILVESTRE, F.T.; CARVALHO, T.S.M.; FRANCISCO, N.; SANTOS, J.E.P.; STAPLES, C.R.; JENKINS, T.; THATCHER, W.W. Effects of differential supplementation of fatty acids during the peripartum and breeding periods of Holstein cows: I. Uterine and metabolic responses, reproduction, and lactation. Journal of Dairy Science, v.94, p.189-204, 2011. DOI: 10.3168/jds.2010-3370.
SKLAN, D.; KAIM, M.; MOALLEM, U.; FOLMAN, Y. Effect of dietary calcium soaps on milk yield, body weight, reproductive hormones, and fertility in first parity and older cows. Journal of Dairy Science, v.77, p.1652-1660, 1994. DOI: $10.3168 / \mathrm{jds}$. S0022-0302(94)77107-1.

STAPLES, C.R.; BURKE, J.M.; THATCHER, W.W. Influence of supplemental fats on reproductive tissues and performance of lactating cows. Journal of Dairy Science, v.81, p.856-871, 1998. DOI: $10.3168 /$ jds.S0022-0302(98)75644-9.

WARD, A.T.; WITTENBERG, K.M.; PRZYBYLSKI, R. Bovine milk fatty acid profiles produced by feeding diets containing solin, flax and canolA. Journal of Dairy Science, v.85, p.1191-1196, 2002. DOI: $10.3168 /$ jds.S0022-0302(02)74182-9.

Received on May 29, 2014 and accepted on March 17, 2015 